\section{Managing Saline and Sodic Soils for Producing Horticultural Crops}

\section{Charles A. Sanchez ${ }^{1}$ and Jeffrey. C. Silvertooth ${ }^{2}$}

Additional index words. irrigation, water quality, salt tolerance, soil amendments, soil analysis

Summary. About $33 \%$ of all irrigated lands worldwide are affected by varying degrees of salinity and sodicity. Soil with an electrical conductivity (EC) of the saturated extract $>4 \mathrm{dS} \cdot \mathrm{m}^{-1}$ is considered saline, but some horticultural crops are negatively affected if salt concentrations in the rooting zone exceed $2 \mathrm{dS} \cdot \mathrm{m}^{-1}$. Salinity effects on plant growth are generally osmotic in nature, but specific toxicities and nutritional balances are known to occur. In addition to the direct toxic effects of $\mathrm{Na}$ salts, Na can negatively impact soil structure. Soil with exchangeable sodium percentages (ESPS) or saturated extract sodium absorption ratios (SARs) $>15$ are considered sodic. Sodic soils tend to deflocculate, become impermeable to water and air, and puddle. Many horticultural crops are sensitive to the deterioration of soil physical properties associated with $\mathrm{Na}$ in soil and irrigation water. This review summarizes important considerations in managing saline and sodic soils for producing horticultural crops. Economically viable management practices may simply involve a minor, inexpensive modification of cultural practices under conditions of low to moderate salinity or a more costly reclamation under conditions of high $\mathrm{Na}$.

'Department of Soil, Water, and Environmenta Sciences, Yuma Agricultural Center, University of Arizona.

${ }^{2}$ Department of Plant Sciences, University of Arizona, Tucson.

The cost of publishing this paper was defrayed in part by the payment of page charges. Under postal regulations, this paper therefore must be hereby marked advertisement solely to indicate this fact.
$\mathrm{P}$

roblems associated with salt and $\mathrm{Na}$-affected soils have existed for thousands of years in locations ranging from Asia, the Middle East, Africa, South America, and North America. For example, one of thecauses for the declineand disappearance of the native American Hohokam civilization in central Arizonais thought to be soil salinization of the Gila River Valley, which they irrigated (Bohrer, 1970). About $33 \%$ of all irrigated land worldwide is made up of saline soils (Yenson and Bedell, 1993). About 6 million ha of irrigated land is lost each year due to drainage and salinization problems (Bohn et al., 1985).

In addition, about 405 million ha of land is associated with saline aquifers. Problems of soil salinity and sodicity occur primarily in arid areas where evapotranspiration exceeds rainfall. However, under certain conditions, soil salinity problems exist in humid regions as well.

In the United States, 5 million ha in the 17 western states is classified as saline (Bohn et al., 1985). Many of these soils are used for producing horticultural crops. Several horticultural crops are sensitive to saline conditions and are strongly affected by the deterioration of soil physical conditions associated with $\mathrm{Na}$. The objective of this paper is to review and summarize various considerations in managing saline and sodic soils used for producing horticultural crops.

\section{Soil considerations}

Chemical. The salt and Nastatus of the soil should be chemically characterized. The salinity status of a soil usually is determined by measuring theelectrical conductivity (EC) of thewater extract from the saturated soil paste. Soils are classified as being saline if $\mathrm{EC}_{\mathrm{e}}$ exceeds $4 \mathrm{dS} \cdot \mathrm{m}^{-1}$ (Table 1). However, many salt-sensitive horticultural crops, such as lettuce (Lactuca sativaL.), are harmed by $\mathrm{EC}_{\mathrm{e}}>2 \mathrm{dS} \cdot \mathrm{m}^{-1}$.

Sodicity refers to an excess of exchangeable Nain thesoil. In addition to direct toxic affects from Na salts, Na negatively influences soil structure, thus rendering soils unsuitable for crop production. Sodic soils often are characterized by dispersed soil particles, low water permeability dueto pore clogging and colloid swelling, poor aeration, high soil pH (>9), and dispersed organic matter (black alkali).

Soils with exchangeable $\mathrm{Na}$ percentages (ESPs) $>15$ are considered sodic. However, ESP values of 5 to 10 may reduce infiltration in some soils. Because determining ESP is tedious, the sodium absorption ratio (SAR) in water extracts from saturated soil pastes is often used.

$$
\mathrm{SAR}_{\mathrm{e}}=(\mathrm{Na}) /((\mathrm{Ca}+\mathrm{Mg}) / 2)^{0.5}
$$

where concentrations are expressed in meg/liter. Although SAR has a chemical basis in the 
Table 1. Classification of salt- and sodium-affected soils.

\begin{tabular}{lcccc}
\hline Criterion & Normal & Saline & Sodic & Saline-Sodic \\
\hline $\mathrm{EC}_{\mathrm{e}}\left(\mathrm{dS} \cdot \mathrm{m}^{-1}\right)$ & $<4$ & $>4$ & $<4$ & $>4$ \\
$\mathrm{SAR}$ & $<15$ & $<15$ & $>15$ & $>15$ \\
\hline
\end{tabular}

Table 2. A comparison of salt levels and moisture contents for three soils.

\begin{tabular}{|c|c|c|c|}
\hline $\begin{array}{l}\text { Salt level or } \\
\text { moisture content }\end{array}$ & Sand & Loam & Muck \\
\hline \multicolumn{4}{|l|}{ Soil situation } \\
\hline $\mathrm{EC}_{\mathrm{e}}\left(\mathrm{dS} \cdot \mathrm{m}^{-1}\right)$ & 2.0 & 2.0 & 2.0 \\
\hline Dry soil weight (kg/15 cm-ha) & $2,400,000$ & $2,128,000$ & 616,000 \\
\hline \multicolumn{4}{|l|}{ At saturation } \\
\hline Water content (\%) & 24 & 40 & 150 \\
\hline Water $\left(\mathrm{kg} \cdot \mathrm{ha}^{-1}\right)$ & 576,000 & 851,200 & 924,000 \\
\hline Salt concentration (ppm) & 1,280 & 1,280 & 1,280 \\
\hline Total salts $\left(\mathrm{kg} \cdot \mathrm{ha}^{-1}\right)$ & 737 & 1,090 & 1,183 \\
\hline \multicolumn{4}{|l|}{ At field capacity } \\
\hline Water content (\%) & 6 & 20 & 140 \\
\hline Water $\left(\mathrm{kg} \cdot \mathrm{ha}^{-1}\right)$ & 144,000 & 425,600 & 862,400 \\
\hline Salt concentration (ppm) & 5,118 & 2,560 & 1,370 \\
\hline
\end{tabular}

theory of cation exchange (Sposito and Mattigod, 1977), we typically measure what has been called the practical $S A R_{e}$ ratio, which is only empirically related to SAR and ESP. Statistical relationships derived from several soils indicate that practical SAR values are about $12 \%<$ SAR values and reasonably close to ESP values (Sposito and Mattigod, 1977). Hence, soils with practical SAR values $>15$ are generally considered sodic(Table 1 ).

Soil-water relationships. Interpretations of soil salinity status and its potential impact on plant growth can be somewhat confounded by soil-water relationships, which are largely influenced by soil texture and soil organic matter content. For example, consider asand, aloam, and a muck soil all having an $\mathrm{EC}_{\mathrm{e}}$ of $2 \mathrm{dS} \cdot \mathrm{m}^{-1}$ and containing $24 \%, 40 \%$, and $150 \%$ moisture at saturation, respectively (Table2). However, at field capacity (about 0.1 bar tension), moisture contents are $6 \%$ for sand, $20 \%$ for loam, and $140 \%$ for muck. Assuming no leaching, precipitation or plant uptake of salts, at field capacity the salt concentration in sand would be almost twice that of loam and almost four times that of muck. These complications are especially important for saltsensitive crops such as lettuce, for which $E C$ values $>2 \mathrm{dS} \cdot \mathrm{m}^{-1}$ adversely affect plant growth in loam, whereas $\mathrm{EC}_{\mathrm{e}}$ values $>1.5 \mathrm{dS} \cdot \mathrm{m}^{-1}$ mightnegatively affect yield in sand.

Hammond (1966) suggested multiplying $\mathrm{EC}_{\mathrm{e}}$ values by one half the ratio, saturation percentage moisture:field capacity moisture, to correctroughly for differences in water relationships among soils. When this type of soil moisture information is not available, a rule of thumb is to multiply values for sandy soils by 2 and values for muck soils by 0.5 before interpretation (Hammond, 1966). More re- cently, as part of a research program directed toward developing technologies for measuring in situ bulk soil salinity ( $\left.E_{2}\right)$, more accurate models have been developed that interrelate $\mathrm{EC}_{\mathrm{a}}$ and $\mathrm{EC}_{e}$ based on selected soil properties (Rhoades 1981; Rhoades et al., 1989a, 1989b, 1990).

Spatial variability. Thesalt and Nastatus of a field typically is determined from a composite soil sample. However, such a protocol ignores variation in salinity across a given field. Managing 10- to 20-ha units based on a composite soil samplemight affect salt-sensitivecrops adversely. Note the variation in EC from across a field in southwestern Arizona before being planted to lettuce (Fig. 1). Lettuce yield and quality would be compromised severely in one corner of this field should the entire field be managed based on the $\mathrm{EC}_{\mathrm{e}}$ of about 2.1 of a composite soil sample.

Detailed mapping of soil salinity from $\mathrm{EC}_{\mathrm{e}}$ measurement is generally impractical. However, field determination of soil-paste electrical conductivities (EC) (Rhoades et al. 1989a) and field measurements of bulk soil salinity $\left(E_{a}\right)$ using four electrode sensors, electromagnetic measurements, or time domain reflectometric sensors show promise as apractical means of assessing field variability (Lesch et al. 1992; Rhoades and Oster, 1986).

Because irrigation efficiencies in the southwestern United States are generally low (large leaching fractions and sometimes tail water) for many horticultural crops, field variability in salinity is not amajor problem at present. However, as irrigation efficiencies are enhanced, site-specific technologies for salt and Na management might prove economical.

\section{Crop considerations}

Osmotic effects. The general effects of bulk soil salinity on plants are osmotic. High salt concentrations in the plant rooting zone hinder the plant's ability to take up water from the soil solution. Plants often counter this osmotic gradient by osmotic adjustment, i.e., increasing their internal solute concentration, by producing organic acids or accumulating salts, usually K. However, this process requires energy that would otherwise be used for plant growth and development.

Tolerances to soil salinity have been established for most important crop species (Bernstein, 1964; 1974). Most economically important horticultural crops have been classified as moderately sensitive and sensitive to salinity. Specific tolerances, with respect to $\mathrm{EC}_{\mathrm{e}}$ values for $0 \%, 10 \%$, $25 \%$, and $50 \%$ yield reductions, are shown for several economically importanthorticultural crops in Table 3. A more complete list can be found in Maas and Hoffman (1977) and Maas (1984). Recent publications establishing tolerances for additional horticultural crops (Francois, 1995) attest to the fact that this is an ongoing area of research.

Specific toxicities. In addition to general salinity effects, many horticultural crops are affected negatively by high concentrations of specific ions such as $\mathrm{Cl}, \mathrm{B}$, and $\mathrm{Na}$ (Fig. 2). Crop tolerances to $\mathrm{Cl}$ and $\mathrm{B}$ have been established for many economically important horticultural crops (Bernstein, 1965; Eaton, 1944; Maas, 1984; Pearson, 1960). For example, understanding the $\mathrm{Cl}$ tolerance for various citrus rootstocks is of utmost importance in selecting the appropriate rootstock

Fig. 1. Variability in soil $E C_{e}$ values in a field in southwestern Arizona (Yuma Valley) before lettuce seeding. (Unpublished data provided by Agro Phosphate Inc.)

$$
\text { y }
$$

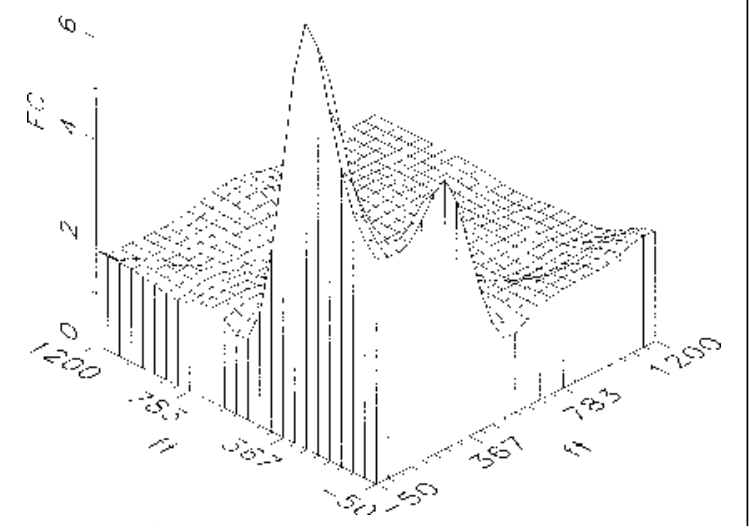


Table 3. Yield potential of selected vegetable and fruit crops ${ }^{2}$ as influenced by soil salinity (EC).

\begin{tabular}{|c|c|c|c|c|}
\hline \multirow[b]{2}{*}{ Crop } & \multicolumn{4}{|c|}{ Yield potential (\%) } \\
\hline & 100 & 90 & 75 & 50 \\
\hline & \multicolumn{3}{|c|}{$E C_{e} d S \cdot m^{-1}$} & \\
\hline \multicolumn{5}{|l|}{ Vegetable } \\
\hline Broccoli (Brassica oleracea L. Italica) & 2.8 & 4.9 & 5.5 & 8.2 \\
\hline Tomato (Lycopersicon esculentum Mill.) & 2.5 & 3.5 & 5.0 & 7.6 \\
\hline Cucumber (Cucumis sativus L.) & 2.5 & 3.3 & 4.4 & 6.3 \\
\hline Celery [Apium graveolens L. var. dulce (Mill) Pers.] & 1.8 & 3.4 & 5.8 & 9.9 \\
\hline Cabbage (Brassica oleracea L. Capitata group) & 1.8 & 2.8 & 4.4 & 7.0 \\
\hline Pepper (Capsicum annuum L. var. annuum) & 1.5 & 2.2 & 3.3 & 5.1 \\
\hline Lettuce (Lactuca sativa L.) & 1.3 & 2.1 & 3.2 & 5.1 \\
\hline Radish (Raphanus sativus L.) & 1.2 & 2.0 & 3.1 & 5.0 \\
\hline Onion (Allium cepa L. cepa group) & 1.2 & 1.8 & 2.8 & 4.3 \\
\hline Carrot (Daucas carota L.) & 1.0 & 1.7 & 2.8 & 4.6 \\
\hline Bean (Phaseolus vulgaris L.) & 1.0 & 1.5 & 2.3 & 3.6 \\
\hline \multicolumn{5}{|l|}{ Fruit } \\
\hline Date palms (Phoenix dactylifera L.) & 4.0 & 6.8 & 11.0 & 18.0 \\
\hline Grapefruit (Citrus paradisi Macf.) & 1.8 & 2.4 & 3.4 & 4.9 \\
\hline Orange (Citrus sinensis L. Osb.) & 1.7 & 2.3 & 3.3 & 4.8 \\
\hline Peach [Prunus persica (L.) Batsch] & 1.7 & 2.2 & 2.9 & 4.1 \\
\hline Grape (Vitas sp.) & 1.5 & 2.5 & 4.1 & 6.7 \\
\hline Plum (Prunus domestica L.) & 1.5 & 2.1 & 2.9 & 4.3 \\
\hline Blackberry (Rubus sp.) & 1.5 & 2.0 & 2.6 & 3.8 \\
\hline Strawberry (Fragaria sp.) & 1.0 & 1.3 & 1.8 & 2.5 \\
\hline
\end{tabular}

${ }^{2}$ Adapted from Maas and Hoffman (1977) and Maas (1984).

for specific conditions of soil and irrigation water (Table 4).

Many horticultural plant species are very sensitiveto Na. Most deciduous fruit crops, citrus, and nut crops are affected by soil ESPlevels as low as 5 (Pearson, 1960). Some vegetable crops are affected by ESP values as low as 10. These effects are observed even where soil physical conditions remain favorable, suggesting the effects are direct Na toxicity.

Nutritional imbalances. Salinity also affects plant growth by inducing nutritional imbalances. For example, high concentrations of monovalent salts in the rooting zone can reduce plant uptake of $\mathrm{Ca}$ (Fig. 3). Another example is bicarbonate-induced deficiencies of the micronutrients $\mathrm{Fe}, \mathrm{Zn}$, and $\mathrm{Mn}$.

Cropping systems. Information of salinity tolerance also should be used in the context of cropping strategies. For example, acommon cropping sequence in the low desert region of the southwestern United States is cotton and lettuce. While cotton is generally tolerant of saline conditions, lettuce is not. Hence, during cotton production, soils should be managed to preclude salt accumulation, which might adversely affect asubsequent crop of lettuce.

\section{Water considerations}

Water quality. The quality of water used for irrigation is a major consideration. The salinity status of water is assessed using EC measure- crop, leaching volumeachieved, and the predicted level of salinity in soil water from using this irrigation water (Rhoades, 1972).

In addition to total salts, the Na concentration of irrigation water is important. The Na hazard of irrigation water often is assessed using the $\mathrm{SAR}_{w}$, the same ratio defined previously for soil extracts $\left(S A R_{e}\right)$. If $S A R_{w}$ values of irrigation water are $>7$ to 10 , low water infiltration and conversion of the soil to sodic conditions may occur. However, the SAR aloneneglects the potential sodium hazard associated with water high in bicarbonates. The carbonate $\left(\mathrm{CO}_{3}{ }^{2-}\right)$ and bicarbonate $\left(\mathrm{HCO}_{3}^{-}\right)$in irrigation water can precipitate $\mathrm{Ca}$, thereby increasing the SAR of irrigation water.

Over the years, several methods have been proposed for predicting the potential $\mathrm{Na}$ hazard associated with carbonate and bicarbonate ions in irrigation water. The residual sodium carbonate (RSC) method was used commonly at one time (Eaton, 1950):

$\mathrm{RSC}=\left[\mathrm{HCO}_{3}^{-}+\mathrm{CO}_{3}^{2-}\right]-\left[\mathrm{Ca}^{2+}+\mathrm{Mg}^{2+}\right]$

Waters with RSC $>2.5$ were considered unsuitable for irrigation purposes; waters with RSC of 1.25 to 2.5 were considered marginal; and waters $<1.25$ were considered safe (Wilcox et al., 1954). The RSC method assumes all $\mathrm{HCO}_{3}^{-}$precipitates and generally overpredicts the $\mathrm{Na}^{+}$hazard of water. This method has been abandoned largely in favor of adjusted SAR methods proposed by others (Bower et al., 1968; Rhoades, 1968; Suarez, 1981). Presently, the adjusted SAR method proposed by Suarez (1981) generally is favored, be-

Fig. 2. Chloride toxicity to furrow-irrigated grapes near
Safford, Ariz. (Photograph courtesy of T. Doerge.) ments. Based on statistical relationships from several waters, total dissolved solids (TDS mg.liter ${ }^{-1}$ ) can be estimated by multiplying $\mathrm{EC}_{\mathrm{w}}\left(\mathrm{dS} \cdot \mathrm{m}^{-1}\right)$ values by 640 .

Evapotranspiration concentrates salts added in irrigation water. Hence, irrigation water with modest amounts of salt can result in saline soil conditions. An assessment of irrigation water suitability must consider the salinity tolerance of the

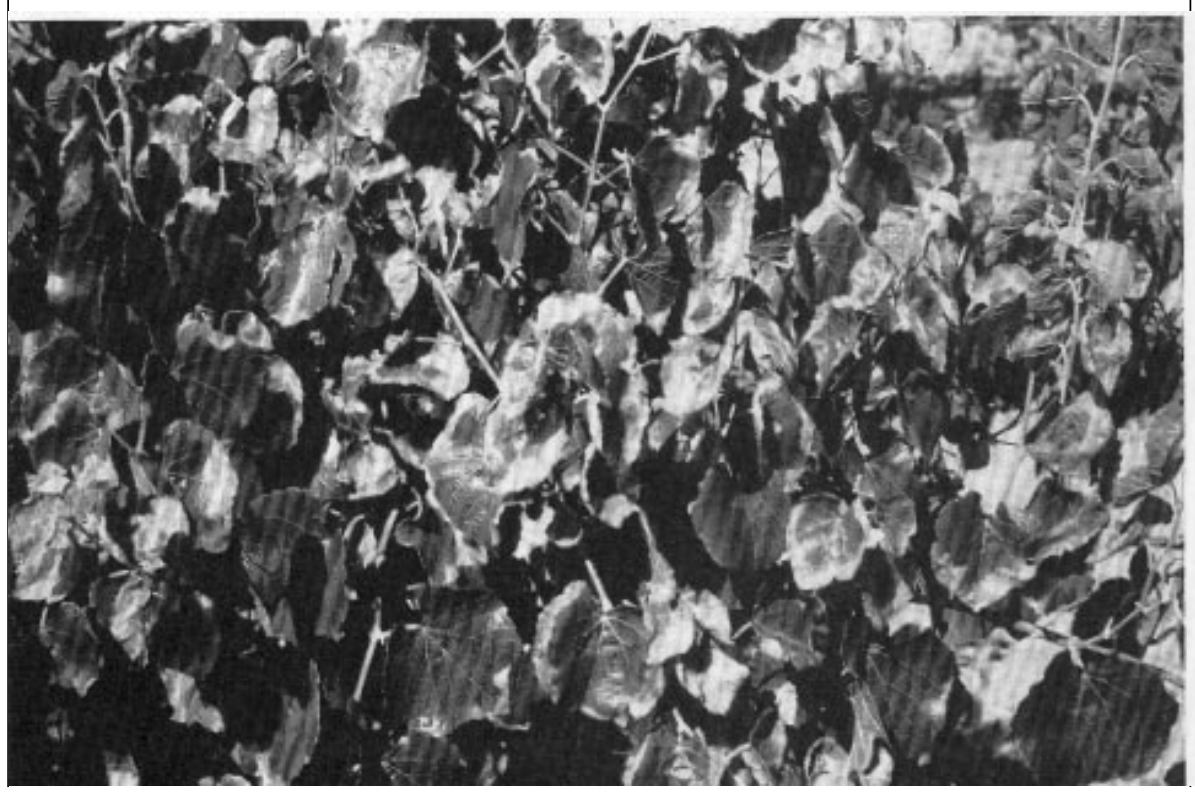


Table 4. Tolerance of citrus rootstocks to chloride in soil $\left(\mathrm{Cl}_{e}\right)$ and irrigation water.

\begin{tabular}{|c|c|c|}
\hline Rootstock & Soil $\left(\mathrm{Cl}_{e}\right)$ & Irrigation water $\left(\mathrm{Cl}_{\mathrm{w}}\right)$ \\
\hline & \multicolumn{2}{|c|}{ meq/liter } \\
\hline Sunki mandarin & \multirow[t]{4}{*}{25.0} & \multirow[t]{4}{*}{16.6} \\
\hline Grapefruit & & \\
\hline Cleopatra mandarin & & \\
\hline Rangpur lime & & \\
\hline Sampson tangelo & \multirow[t]{4}{*}{15.0} & \multirow[t]{4}{*}{10.0} \\
\hline Rough lemon & & \\
\hline Sour orange & & \\
\hline Ronkan mandarin & & \\
\hline Citrumelo & \multirow[t]{8}{*}{10.0} & \multirow[t]{8}{*}{6.7} \\
\hline Trifoliate orange & & \\
\hline Cuban shaddock & & \\
\hline Calamondin & & \\
\hline Sweet orange & & \\
\hline Savage citrange & & \\
\hline Rusk citrange & & \\
\hline Troyer citrange & & \\
\hline
\end{tabular}

${ }^{7}$ Adapted from Maas (1984).

cause it is simpler and more accurate than alternative procedures. This equation is discussed in moredetail below with respect to leaching requirements.

Irrigation method. Irrigation method and volume of water applied have a pronounced influence on salt accumulation and distribution (Ayers and Westcot, 1989; Bernstein and Francois, 1973). Datacollected from a citrus experiment conducted in southwestern Arizona show various salt distribution patterns as a result of different irrigation methods (Fig. 4). Flood irrigation and an appropriate leaching fraction generally move salts below the root zone. Similar results can be obtained with a properly managed sprinkler irrigation system. However, in hot, arid climates, evaporation loss during sprinkling might increase the salinity of water moving into the soil (Ayers and Westcot, 1989). Robinson's (1973) study suggests that the concentration of salts in sprinkler water for saltsensitive crops is generally not a problem in the center of the field but may be a problem near the edge of the field, where evaporation losses are higher. Another major concern with sprinkler irrigation is the potential for leaf burn. Harding et al. (1958) reported that water normally suitable for surface irrigation may be harmful to citrus. They found that leaf burn and defoliation of the lower part of citrus trees can result from sprinkling water having $\mathrm{EC}_{\mathrm{w}}$ values of 0.8 to $1.5 \mathrm{dS} \cdot \mathrm{m}^{-1}$. Tolerances of crops to foliar injury using sprinkler irrigation can be found in Maas (1984) and Ayers and Westcot (1989).

With furrow and pressurized irrigation, solublesalts in the soil movewith thewetting front, concentrating at its termination or at its convergence with another wetting front. In drip-irrigated plots, water moves away from the emitter and salts concentrate where water evaporates. In furrowirrigated crops, water movement is from the furrow into the bed via capillary flow. When adjacent furrows are irrigated, salts concentrate in the center of the intervening bed (Fig. 5). Manipulating bed shapeand planting arrangement are strategies often used to avoid salt damage in furrow-irrigated row crops. This is discussed in more detail below. Because drip irrigation maintains more constant favorable conditions of soil moisture, plants tolerate higher levels of salinity than with furrow irrigation (Bernstein and Francois, 1973).

\section{Management strategies}

Leaching. Leaching excess salts and maintaining favorable salt balance remains the best strategy to prevent detrimental salt accumulation in the soil profile. Leaching also can be used to reclaim nonsodic saline soils. Most leaching strategies are based on asteady-stateassumption of mass balance and are calculated by

$$
L F=D_{d w} / D_{i w}=E C_{i w} / E C_{d w}
$$

where LF (leaching fraction) is the fraction of water that leaves the root zoneas drainage water, $D_{d w}$ and $D_{i w}$ are the volumes of drainage and irrigation water, respectively, and $\mathrm{EC}_{\mathrm{iw}}$ and $\mathrm{EC}_{\mathrm{dw}}$ are the $E C$ of irrigation water and drainage water, respectively. Typically $\mathrm{EC}_{\mathrm{dw}}$ is selected from crop tolerance data(such as that presented in Table 4) to calculate the desired leaching fraction. Because salt concentrations of saturation extracts (EC values) aretypically more dilute than the salt concentration of the actual drainage water under field con- ditions, using $\mathrm{EC}_{\mathrm{e}}$ values in the denominator of $\mathrm{Eq}$. [3] $\left(\mathrm{EC}_{\mathrm{dw}}\right)$ traditionally has exaggerated the calculated leaching fraction. As noted above, information on soil texture and soil moisture can be used to estimate bulk salinity in the rooting zone (EC values).

This above relationship also ignores ion uptake by plants and precipitation and dissolution reactions of carbonates in the rooting zone. Errors associated with the latter could have disastrous effects when water high in sodium or bicarbonate are used for irrigation. Several approaches have been used to estimate leaching fractions in which calcium carbonate tends to precipitate or dissolve in soils. Bower et al. (1968) proposed using a modified saturation index based on Langelier's index. However, this equation overpredicted the sodium hazard associated with drainage waters (Oster and Rhoades, 1975). Rhoades (1968) modified Langliers's index to include empirically derived parameters aimed at predicting mineral weathering. It worked well for many western soils. However, the value of the weathering coefficient varies somewhat with soil-water combination (O'Connor, 1971; Oster and Rhoades, 1975), thus limiting its

Fig. 3. Celery blackheart, a calcium-related physiological disorder. In this case blackheart was caused by a high concentration of monovalent salts in the rooting zone.

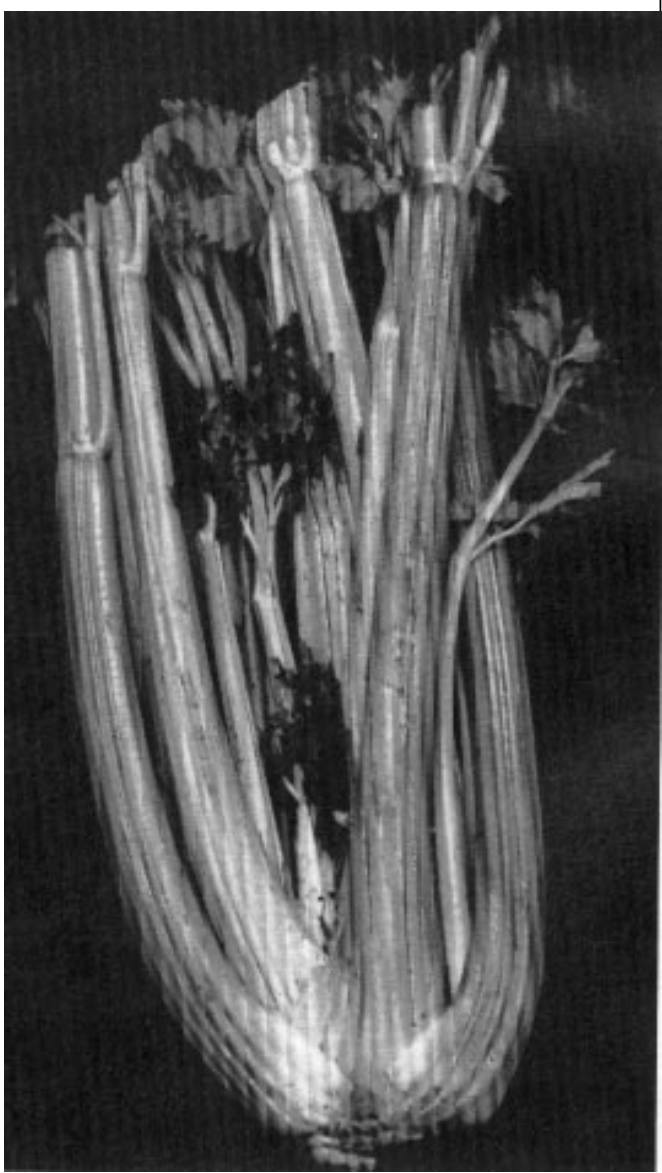


predictive potential. Suarez (1981) proposed the following:

$$
\operatorname{Adj} \mathrm{SAR}_{\mathrm{dw}}=\left(\mathrm{Na}_{\mathrm{w}} / \mathrm{LF}\right) /\left\{\left(\mathrm{Mg}_{\mathrm{iw}} / \mathrm{LF}+\mathrm{X}\left(\mathrm{P}_{\mathrm{cOR}}\right)^{1 / 3}\right\}^{1 / 2}[4]\right.
$$

where $\mathrm{Na}_{\text {iw }}$ and $\mathrm{Mg}_{\text {iw }}$ are the concentrations of $\mathrm{Na}$ and $\mathrm{Mg}$ in irrigation water as $\mathrm{mmol} \cdot$ liter $^{-1}, \mathrm{P}_{\mathrm{CO}}$ is the partial pressure of $\mathrm{CO}_{2}$ in the soil, and $\mathrm{X}$ is selected from a table (Suarez, 1981) based on the $\mathrm{HCO}_{3}^{-} /$Ca ratio and theionic strength of theirrigation water (which is estimated by $\mathrm{EC}_{w}$ ). Because this relationship is not very sensitive to $P_{C O 2}$, rough estimates are usually satisfactory. Equation [4] attempts to address shortcomings in previous equations by calculating equilibrium $\mathrm{pH}$ rather than assuming one. This equation is simpler and generally more accurate than others used and has found widespread application in thewestern United States.

Drainage. A prerequisite to using leaching as amanagement tool is good internal and external drainage. Poor internal soil drainage caused by surface crusting, hardpans, and sodic conditions often is managed by tillage and soil amendments. Deep chiseling is performed at least onceayear on most cropland in the low desert of southwestern United States (Fig. 6). When sodic conditions exist, an aggressivesoil amendment program usually is required.

External drainage on most farmland in the western United States is maintained through an intricate network of open drains and tile drains. In some situations, drainage wells are required.

Planting configuration, bed arrangement, and irrigation. Water movement in furrow irrigation is from the furrow into the bed. This can result in localized elevated salinity, which can harm seedling plants (Bernstein and Fireman, 1957), even under low to moderately saline conditions. Many crops, such as lettuce and broccoli, are seeded in two rows near the outer edge of the bed with a ridge or corrugation in the center. This arrangement places young seedlings out of the zone of highest salt accumulation. For crops such as cauliflower, which typically are seeded one row per bed, plants often are offset from the bed center, or only every other furrow is irrigated during stand establishment.

Other strategies al so avoid gradients caused by furrow irrigation. Sprinkler irrigation during stand establishment has become a widespread practice for vegetables produced in the low desert (Hartz, 1994). Sprinkling moves salts with water downward below the seed zone. Crops such as sweet corn can be planted in the water-furrow or planted in mulched moist beds to avoid salt accumulation associated with furrow irrigation. More details on options for bed and planting configurations with regard to salinity management can be found in Ayers and Westcot (1989).

Fertilizer management. Many fertilizers contain solublesalts in high concentrations. Therefore, nutrient source, rate, timing, and placement are important considerations in the production of horticultural crops. Salt indices for most commercial fertilizer products havebeen reported by Rader (1943). For example, KCl has asalt index 2.5 times that of $\mathrm{K}_{2} \mathrm{SO}_{4}$. Generally, band application of fertilizers with high salt indices near seedlings should be avoided. An interesting example where source

Fig. 4. Salt distribution patterns below a 'Valencia' orange grove in southwestern Arizona (Wellton Mesa) as influenced by irrigation system. (Unpublished data provided by $R$. Roth.)
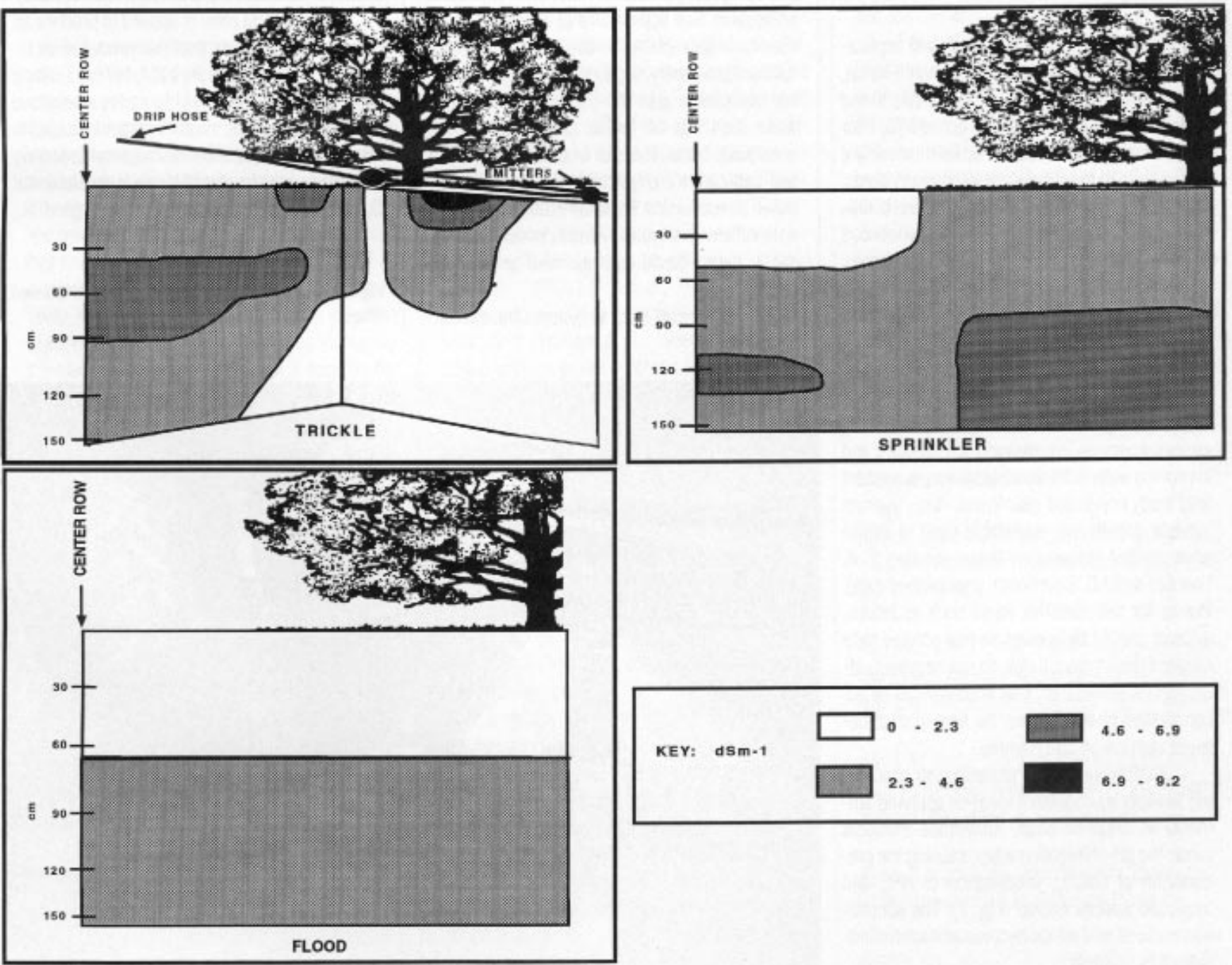


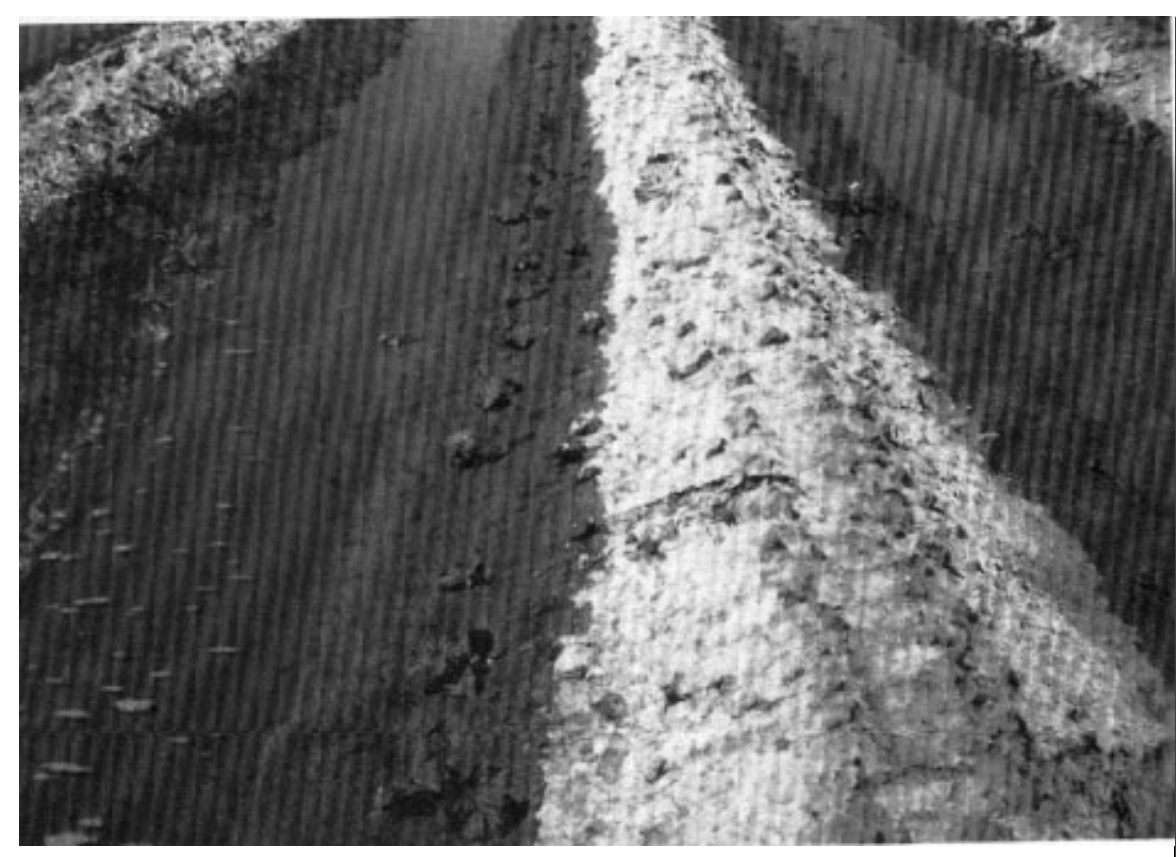

Fig. 5. Salt distribution in furrow-irrigated melons. Note melons are seeded on the south side of the bed away from the high concentrations of salts in the bed center. (Photograph courtesy of $T$. Doerge.)

may be important, even with broadcast application, is for lettuce production in southern Florida. During prolonged periods of no rainfall, $\mathrm{K}$ and other salts have the potential to accumulate near the soil surface as a result of upward movement with water from the subsurface irrigation systems. Field studies have shown that under these conditions lettuce yield reduction is more pronounced when $\mathrm{KCl}$ is used compared to $\mathrm{K}_{2} \mathrm{SO}_{4}$ (C.A. Sanchez, unpublished data).

The salt content of amendments such as gypsum and manures also should be considered. For many soils in the western United States, gypsum application is a useful management practice for precluding sodium accumulation on the soil's exchangecomplex, maintaining soil structure, and improving water infiltration. However, in a recent field study conducted near Yuma, Ariz., gypsum reduced growth and marketable yield of lettuce when applied immediately before seeding (C.A. Sanchez and J.C. Silvertooth, unpublished data). Hence, for salt-sensitive crops such as lettuce, gypsum should be applied so that soluble salts released during dissolution do not negatively affect lettuce production. This probably can be accomplished by lengthening the time interval between application and planting.

Another interesting phenomenon concerning fertilizer management involves applying ammonia in irrigation water. Anhydrous ammonia raises the $\mathrm{pH}$ of irrigation water, causing the precipitation of $\mathrm{CaCO}_{3}$, volatilization of $\mathrm{NH}_{3}$, and increased sodium hazard (Fig. 7). The simultaneous use of acid with anhydrous ammonia eliminates this problem.
Soil amendments and water treatments. Soil amendments and water treatments often offer a practical and economical means for managing many problems common to saline and sodic soils. Soil applications of amendments are used for initial reclamation and long-term maintenance of soil quality. In general, water applications are intended to alter the chemistry of irrigation water such that no further degradation in soil quality will occur. Rates of amendments used for soil application are typically large and primarily based on economics. For water treatments, rates of amendments are typically much smaller and are nearly always based on solubilities and stoichiometry.

Amendments such as gypsum and elemen- tal Shavebeen used for years. Gypsum is primarily used on Na-affected soils as a source of $\mathrm{Ca}^{2+}$ to displace $\mathrm{Na}^{+}$from the soil's colloidal exchange complex. The exchange flocculates soil particles (bunching of particles into larger aggregates). The $\mathrm{Ca}^{2+}$ ions reverse the effect of $\mathrm{Na}^{+}$ions, which tend to disperse soil particles and restrict water infiltration. The resulting displaced $\mathrm{Na}^{+}$ions are leached readily from the soil profile. Gypsum is a neutral salt that does not directly reduce $\mathrm{pH}$. However, it can indirectly lower the $\mathrm{pH}$ of sodic soils by reducing the hydrolysis reactions associated with $\mathrm{Na}$ ions on the exchange complex. Gypsum often can reduce surface sealing and improve water infiltration in nonsodic soils by releasing electrolytes into percolating water (Ben-Hur et al., 1992; Shainberg et al., 1990; Warrington et al., 1989).

Eemental $S$ is also a common soil amendment. Sulfur added to soil undergoes a slow biochemical oxidation to sulfuric acid. This affects the soil first by neutralizing soil bases and lowering $\mathrm{pH}$ directly, and second by dissolving native soil $\mathrm{CaCO}_{3}$ to form gypsum, which then acts as described above. Iron pyrites also have been suggested as soil amendments (McGeorge and Breazeale, 1955). Like elemental S, iron pyrites oxidizeto sulfuricacid (Banath and Holland, 1976).

Sulfuric acid often is applied to produce an effect more immediate than that produced by elemental S (Miyamoto et al., 1974; 1975a). Sulfuric acid can beadded directly to the soil by specialized equipment or used as a water treatment. Studies in Arizona showed that water infiltration and seedling emergence were increased by gypsum, elemental $\mathrm{S}$, or acid applied to the soil (McGeorge et al.,

Fig. 6. Chisel used routinely in the southwestern United States.

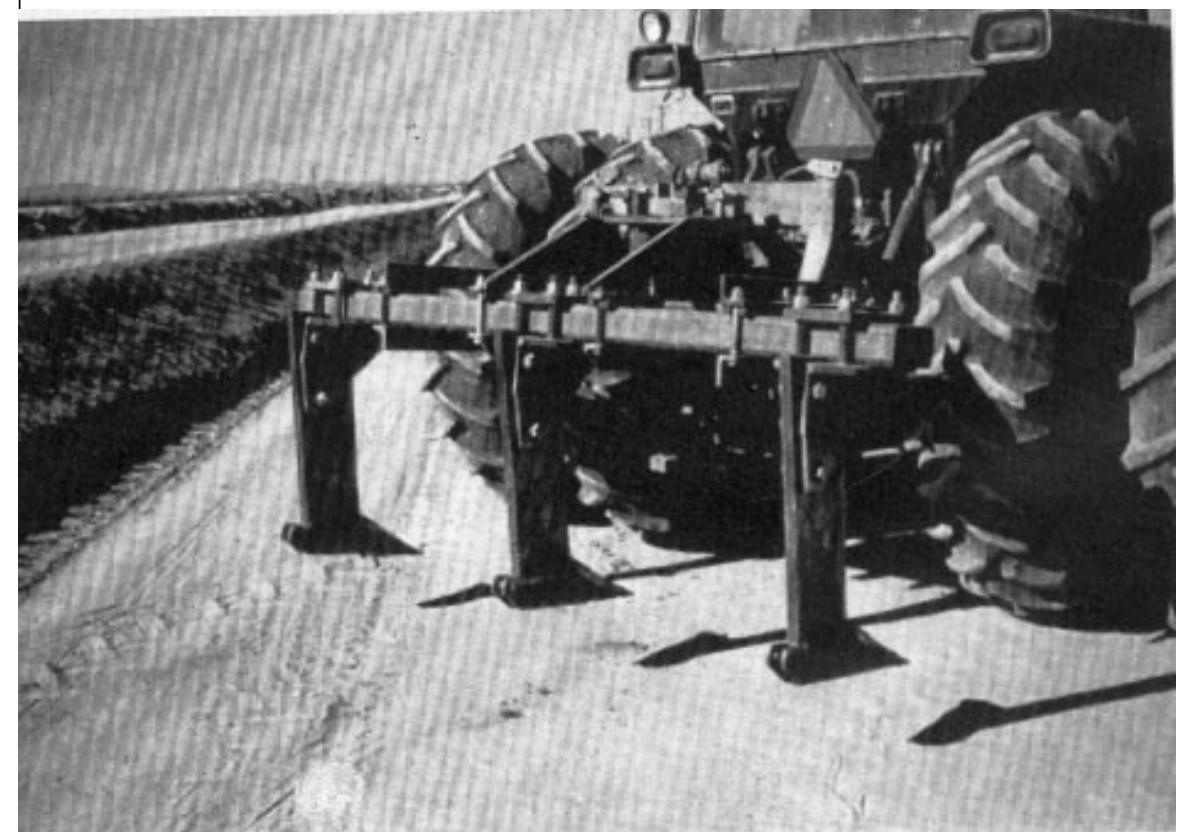




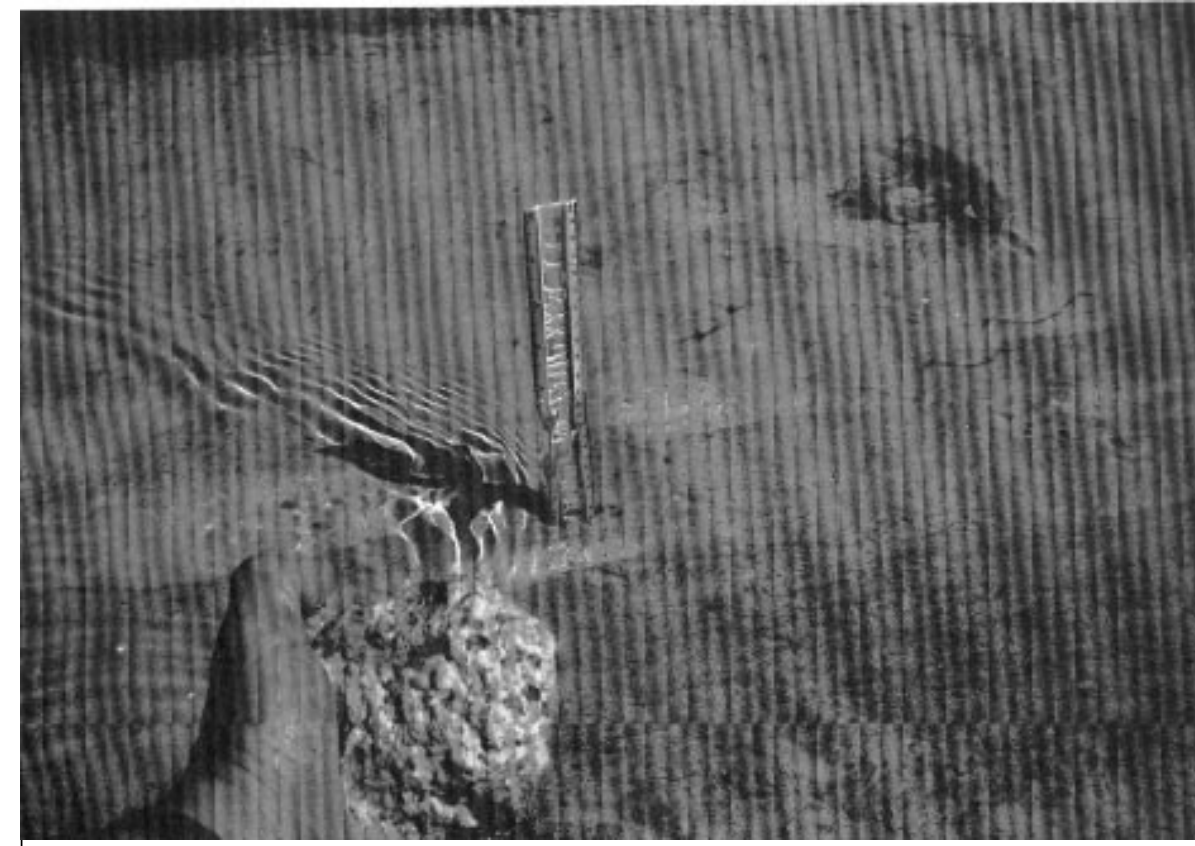

Fig. 7. Precipitation of carbonates in irrigation ditches after application of ammoniacal fertilizer. (Photograph courtesy of J. Stroehlein.)

1956). Because of the corrosive nature of sulfuric acid, other acid materials or acid-forming products have been used successfully as less hazardous substitutes. Acid or acid-forming amendments often are used to obtain the added benefit of enhanced $P$ and micronutrient availability (Stroehlein and Pennington, 1986). Sulfuric acid and other acid-forming liquid materials have been highly effective when added to irrigation water as a water treatment (Stroehlein and Pennington, 1986; Yahia et al., 1976). Acid added to irrigation water not only improves infiltration by increasing the electrolyte concentration, but it reduces the carbonate and bicarbonate hazard of irrigation waters (Miyamoto et al., 1975b).

Calcium polysulfideand ammonium polysulfide also are used as water treatments to improve infiltration (Stroehlein and Pennington, 1986). These materials areinitially basic and react to form colloidal S. The $\mathrm{Ca}^{2+}$ or ammonium $\left(\mathrm{NH}_{4}^{+}\right)$ion can replace $\mathrm{Na}^{+}$on the exchangecomplex. Ammonium and $\mathrm{S}$ are then oxidized to form acid $\left(\mathrm{H}^{+}\right)$. Studies have shown improved infiltration with these products (E-Tayib et al., 1979; Cairns and Beaton, 1976). Not all of the beneficial effects can be attributed to Sand ammonium oxidation. Onefield study in Arizona showed an immediate increase in infiltration beforeoxidation could occur (Stroehlein and Pennington, 1986), probably due to electrolyte effects.

Synthetic polymers werefirst investigated in the 1950s and 1960s. An extensive series of studies conducted in Arizona with polymers available at the time resulted in reduced soil compaction, improved stands, and increased yields compared to untreated controls (Fuller et al., 1953). Although effective, most of these products evaluated in the 1950 s and 1960 s could not be used economically under field conditions.

Synthetic polymers such as polyacrylamide (PAM), polyvinyl alcohol (PVA), and polysaccharides have more recently shown promising results in research studies. Reduced soil surface crusting (Helalia and Letey, 1989; Terry and Nelson, 1986; Wood and Oster, 1985), improved aggregation and reduced clay dispersion (Aly and Lety, 1988), enhanced stand establishment (Cook and Nelson, 1986; Wallace and Wallace, 1986), reduced soil erosion with furrow and sprinkler irrigation (Ben Hur et al., 1990; Lentz et al., 1992; Levy et al., 1992), and improved reclamation of saline and sodic soils (Wallace et al., 1986) have been reported with the use of synthetic polymers.

Several studies in Israel and theUnited States showed improved infiltration with PAM and other polymers (Ben-Hur et al., 1989; Levy et al., 1992). In most of these studies slaking and dispersion were the dominant mechanisms limiting water intake. However, onestudy showed polymers to be effectivein reducing clay swelling (Emerson, 1963). Shainberg et al. (1990) found that polymers increased water infiltration 3-fold over untreated soils. When gypsum was added with the polymer, infiltration increased another 3-fold over the polymer treatment alone.

Some researchers reported that synthetic polymers may be useful tools for managing and reclaiming sodic soils. Allison (1952) reported an increase in aggregate stability in several salinesodic soils that weretreated with polymers. Wallace et al. (1986) found that PAM added to a sodic soil improved soil aggregation, increased water penetration, and improved crop seedling emergence. Other researchers, however, found that polymers used alone were less effective in sodic soils. Aly and Lety (1990) found that the stability of aggregates treated with polymers decreased as the soil SARincreased from 1 to 15. Zahow and Amrheim (1992) found increased hydraulic conductivity from polymer addition when the soil had an ESP $<15$, but found little or no increase when the soil ESP exceeded 15. However, these workers did find that synthetic polymers used in combination with gypsum increased hydraulic conductivity 4-fold over gypsum alone. These results underscore the need for a Ca source when reclaiming sodic soils and illustrate the apparent synergistic effects of gypsum and synthetic polymers.

\section{Conclusions}

Many economically important horticultural crops are sensitive to soil and water salinity and to the deterioration of soil physical properties associated with $\mathrm{Na}$ in soil and irrigation water. Therefore, soil chemical and physical properties, crop tolerance, water quality, fertilization, and irrigation method are important considerations for the production of horticultural crops. This is especially true in the southwestern United States, where warm winter temperatures favor production of many fruit and vegetable crops, but problems of salinity and sodicity are commonplace.

For purposes of organization we have outlined important considerations individually, but in reality they must beconsidered concurrently. Over the years, researchers have developed and calibrated anumber of useful diagnostic and prognostic tools for dealing with salt and Na-related problems. Once problems (or the potential for problems) are identified, profitable production of horticultural crops depends on the selection of an economically viable management strategy. This may simply involve a minor, inexpensive modification of cultural practices under conditions of low to moderate salinity, or more costly reclamation under conditions of high $\mathrm{Na}$.

\section{Literature Cited}

Allison, L.E. 1952. Effect of synthetic polyelectroIytes on the structure of salineand alkali soils. Soil Sci. 73:443-454.

Aly, S.M. and J. Letey. 1988. Polymer and water quality effects on the flocculation of montmorillonite. Soil Sci. Soc. Amer. J. 52:1453-1458.

Aly, S.M. and J. Letey. 1990. Physical properties of sodium treated soil as affected by two polymers. Soil Sci. Soc. Amer. J. 54:501-504.

Ayers, R.S. and D.W. Westcot. 1989. Water quality for agriculture. FAO Irr. Drainage Paper 29.

Banath, C.L. and J.F. Holland. 1976. Iron pyrites 
as a sulfur fertilizer in an alkaline soil. Austral. J. Agr. Animal Husb. 16:376-381.

Ben-Hur, M., J. Faris, M. Malik, and J. Lety. 1989. Polymers as soil conditioners under consecutive irrigations and rainfall. Soil Sci. Soc. Amer. J. 53:1173-1177.

Ben Hur, M., J. Lety, and I. Shainberg. 1990 Polymer effects on erosion under laboratory rainfall simulator conditions. Soil Sci. Soc. Amer. J. 54:1092-1095.

Ben-Hur, M., R. Stern, A.J. van der Merwe, and I. Shainberg. 1992. Slope and gypsum effects on infiltration and erodability of dispersive and nondispersive soils. Soil Sci. Soc. Amer. J. 56:1571-1576.

Bernstein, L. 1964. Salt tolerance of plants. U.S. Dept. of Agr. Info. Bul. 283.

Bernstein, L. 1965. Salt tolerance of fruit crops. U.S. Dept. of Agr. Info. Bul. 292.

Bernstein, L. 1974. Crop growth and salinity. In: J. van Schilfgaarde (ed.). Drainage for agriculture. Agronomy 17:39-56.

Bernstein, L. and M. Fireman. 1957. Laboratory studies on salt distribution in furrow irrigated soil with special reference to pre-emergence period. Soil Sci. 83:249-263

Bernstein L. and L.E. Francois. 1973. Comparisons of drip, furrow, and sprinkler irrigation. Soil Sci. 115:73-86.

Bohn, H.L., B.L. McNeal, and G.A. O'Connor 1985. Soil chemistry. 2nd ed. Wiley, New York.

Bohrer, V.L. 1970. Ethnobotanical aspects of Snaketown, a Hohokam village in southern Arizona. Amer. Antiquity 35:413-430.

Bower, C.A., G. Ogata, and J.M. Tucker. 1968. Sodium hazard of irrigation waters as influenced by leaching fraction and by precipitation or solution of calcium carbonate. Soil Sci. 106:29-34.

Cairns, R.R., and J.D. Beaton. 1976. Improving a solonetzic soil by nitrogen-sulfur materials. Sulfur Inst. J. 12:10-12.

Cook, D.F. and S.D. Nelson. 1986. Effect of polyacrylamide on seedling emergence in crust-forming soils. Soil Sci. 141:328-333.

El-Tayib, Y.M., J. Lety, and R. Branson. 1979. Sulfur compounds in water treatment-effect on infiltration rate. Sulfur 3:7-11.
Eaton, F.M. 1944. Deficiency, toxicity, and accumulation of boron in plants. J. Agr. Res. 69:237-277.

Eaton, F.M. 1950. Significance of carbonates in irrigation waters. Soil Sci. 69:123-133.

Emerson, W.W. 1963. The effect of polymers on the swelling of montmorillonite. J. Soil Sci. 14:52-63.

Francois, L.E. 1995. Salinity effects on bud yield and vegetative growth of artichoke (Cynara scolymus L.). HortScience 30:69-71.

Fuller, W.H., N.V. Gomness, and L.V. Sherwood. 1953. The influence of soil aggregate stabilizers on stand, composition, and yield of crops on calcareous soils of southern Arizona. Univ. Arizona Tech. Bul. 129

Hammond, L.C. 1966. Soil-water-salinity-plant relationships. Proc. Soil and Crop Sci. Soc. Fla. 26:257-264.

Harding, R.B., M.P. Miller, and M. Fireman. 1958 Absorption of salts by citrus leaves during sprinkling with water suitable for surface irrigation. Proc. Amer. Soc. Hort. Sci. 71:248-256.

Hartz, T.K. 1994. Minimizing environmental stress in field establishment of vegetablecrops in the southwestern United States. HortTechnology 4:29-34.

Helalia, A.M. and J. Letey. 1989. Effects of different polymers on seedling emergence, aggregate stability, and crust hardness. Soil Sci. 148:199-203.

Lentz, R.D., I. Shainberg, R.E Sojka, and D.L. Carter. 1992. Preventing irrigation furrow erosion with small applications of polymers. Soil Sci. Soc. Amer. J. 56:1926-1932.

Lesch, S.M., J.D. Rhoades, L.J. Lund, and D.L. Corwin. 1992. Mapping salinity using calibrated electromagnetic measurements.. Soil Sci. Soc. Amer. J. 56:540-548.

Levy, G.J., J. Levin, M. Gal, M. Ben-Hur, and I. Shainberg. 1992. Polymers' effects on infiltration and soil erosion during consecutivesimulated sprinkler irrigations. Soil Sci. Soc. Amer. J. 56:902-907.

Maas, EV. 1984. Salt tolerance of plants. In: B.R. Christie (ed.). The handbook of plant science in agriculture. CRC Press, Boca Raton, Fla.

Maas, E.V. and G.J. Hoffman. 1977. Crop salt tolerance - Current assessment. Amer. Soc. Civil Eng. Proc. J. Irr. Drainage. Div. 103:115-131.

McGeorge, W.T. and E.L. Breazeale. 1955. The value of pyrite and Pyrhotite as soil conditioners.
Univ. Arizona Agr. Expt. Sta. Rpt. 124.

McGeorge, W.T., EL. Breazeale, and J.T. Abbott. 1956. Polysulfides as soil conditioners. Univ. Arizona. Bul. 131.

Miyamoto, S., H.L. Bohn, J. Ryan, and M.S. Yee. 1974. Effects of sulfuric acid and sulfur dioxide on aggregate stability of calcareous soils. Soil Sci. 118:299-303.

Miyamoto, S., R.J. Prather, and J.L. Stroehlein. 1975a Sulfuric acid and leaching requirement for reclaiming sodium-affected soils. Plant Soil. 43:773-585.

Miyamoto, S., R.J. Prather, and J.L. Stroehlein. 1975b. Sulfuric acid for controlling calcite precipitation. Soil Sci. 120:264-271.

O'Connor, G.A. 1971. Testing sodium hazard predictions. Soil Sci. Soc. Amer. Proc. 35:510-512.

Oster, J.D. and J.D. Rhoades. 1975. Calculated drainage compositions and salt burdens resulting from irrigation with river waters in the western United States. J. Environ. Qual. 4:73-79.

Pearson. G.A. 1960. Tolerance of crops to exchangeable sodium. USDA Info. Bul 216.

Rader, L.F. 1943. Salt index for fertilizers. Soil Sci. 55:201-208.

Rhoades, J.D. 1968. Leaching requirement for exchangeablesodium control. Soil Sci. Soc. Amer. Proc. 32:652-656.

Rhoades, J.D. 1972. Quality of water for irrigation. Soil Sci. 113:277-284.

Rhoades, J.D. 1981. Predicting bulk soil electrical conductivity versus saturation paste extract electrical conductivity calibrations from soil properties. Soil Sci. Soc. Amer. J. 45:42-44.

Rhoades, J.D. and J.D. Oster. 1986. Solute content, p. 985-1006. In: A. Klute (ed.). Methods of soil analysis. Part 1. 2nd ed. Monog 9. ASA and Soil Sci. Soc. Amer., Madison, Wis.

Rhoades, J.D., N.A. Manteghi, P.J. Shouse, and A.J. Alves. 1989a. Estimating soil salinity from saturated soil-paste electrical conductivity. Soil Sci. Soc. Amer. J. 53:428-433.

Rhoades, J.D., N.A. Manteghi, P.J. Shouse, and W.J. Alves. 1989b. Soil electrical conductivity and soil salinity: New formulations and calibrations. Soil Sci. Soc. Amer. J. 53:433-439.

Rhoades, J.D., P.J. Shouse, W.J. Alves, N.A. 
Manteghi, and S.M. Lesch. 1990. Determining soil salinity from soil electrical conductivity using different models and estimates. Soil Sci. Soc. Amer. J. 54:46-54.

Robinson, L.A. 1973. Increase in conductivity of irrigation water during sprinkling. Agron. J. 65:130.

Shainberg, I., D.N. Warrington, andP. Rengasanmy. 1990. Water quality and PAM interactions in reducing surface sealing. Soil Sci. 149:301-307.

Sposito, G. and S.V. Mattigod. 1977. On thechemical foundation of the sodium absorption ratio. Soil Sci. Soc. Amer. J. 41:323-329.

Stroehlein, J.L. and D.A. Pennington. 1986. Use of sulfur compounds for soil and irrigation water treatments. Agronomy 27:435-454.

Suarez, D.L. 1981. Relationship between $\mathrm{pH}_{\mathrm{c}}$ and sodium adsorption ratio (SAR) and an alternative method of estimating SAR of soil or drainage waters. Soil Sci. Soc. Amer. J. 45:469-475.

Terry, R.E and S.S. Nelson. 1986. Effects of polyacrylamide and irrigation method on soil physical properties. Soil Sci. 141:317-320.

Wallace, A. and G.A. Wallace. 1986. Effects of soil conditioners on emergence and growth of tomato, cotton, and lettuce seedlings. Soil Sci. 141:313-316.

Wallace, A, G.A. Wallace, and A.M. Abouzamam. 1986. Amelioration of sodic soils with polymers. Soil Sci. 141:359-362.

Warrington, D., I. Shainberg, M. Agassi, and J. Morin. 1989. Slope and phosphogypsum's effect on runoff and erosion. Soil Sci. Soc. Amer. J. 53:1201-1205.

Wilcox, L.V., G.Y. Blair, and C.A. Bower. 1954. Effect of bicarbonate on suitability of water for irrigation. Soil Sci. 77:259-266.

Wood, J.D. and J.D. Oster. 1985. The effect of cellulose xanthate and polyvinyl alcohol on infiltration, erosion, and crusting at different sodium levels. Soil Sci. 139:243-249.

Yahia, T.A., S. Miyamoto, and J.L. Stroehlein. 1975. Effect of surface applied sulfuric acid on water penetration into dry calcareous and sodic soils. Soil Sci. Soc. Amer. Proc. 39:1201-1204.

Yenson, N.P. and J.L. Bedell. 1993. Considerations for the selection, adaptation, and application of halophyte crops to highly saline desert environments as exemplified by the long-term development of cereal and forage cultivars of Distichlis spp. (Poaceae), p. 305-313. In: H. Leith and A. Al Masoom (ed.). Toward the rational use of high salinity tolerant plants. vol. 2. Kluwer Academic Publishers, The Netherlands.

Zahow, M.F. and C. Amrheim. 1992. Reclamation of asaline sodic soil using synthetic polymers and gypsum. Soil Sci. Soc. Amer. J. 56:1257-1260. 